\title{
Profil Negosiator Bisnis Wanita Pengusaha
}

\author{
YUSUF HAMDAN, ${ }^{1}$ ANNE RATNASARI, ${ }^{2}$ AZIZ TAUFIK HIRZI ${ }^{3}$ \\ 1,2,3 Fakultas IImu Komunikasi Unisba, JI. Tamansari No. 1 Bandung \\ email: ${ }^{1}$ yusuf.hamdan@gmail.com, 2anne_ratna @yahoo.co.id, 3azizhirzi@yahoo.com
}

\begin{abstract}
This study is concerning the profile of entrepreneurs women business negotiation skills in marketing products and services. The aim of this research is to determine the ability of business negotiation in order to establish cooperation and competition, the use of verbal and nonverbal messages, as well as inhibiting factors in marketing products and services. The research applied qualitative methods with a single case study approach. Data collected by observation, literature study and through interviews. informants of this research were women who are member of Association of Indonesia Entrepreneurs Women (IWAPI) of West J ava. The findings of research on the ability of business negotiations to establish cooperation through negotiation phase including exploration, offerings, bargaining, completion, and validation. They did not compete, but they cooperate with others, and had personal characteristics as a strong negotiator, using a clear, concise, and positive meaningful verbal messages, whereas on nonverbal cues they paid attention on facial expression, eye contact, hand gestures, and the use of appropriate clothing.
\end{abstract}

Keywords: profile, negotiation, business, marketing, products, services.

\begin{abstract}
Abstrak. Penelitian ini tentang profil kemampuan negosiasi bisnis wanita pengusaha dalam memasarkan produk dan jasa. Tujuannya untuk mengetahui kemampuan negosiasi bisnis untuk membangun kerjasama, dan bersaing, penggunaaan pesan verbal dan nonverbal, serta faktor penghambat dalam memasarkan produk dan jasa. Metode penelitian ini kualitatif dengan studi kasus tunggal. Pengumpulan datanya dengan observasi, wawancara mendalam, serta kepustakaan. Informan penelitian ini wanita pengusaha anggota I katan Pengusaha Wanita (IWAPI) Jawa Barat. Temuan penelitian tentang kemampuan negosiasi bisnis untuk membangun kerjasama melalui tahap negosiasi mencakup eksplorasi, penawaran, tawar-menawar, penyelesaian, dan pengesahan. Mereka tidak bersaing, melainkan bekerjasama dengan pihak lain, dan memiliki karakteristik personal sebagai negosiator cukup kuat, menggunakan pesan verbal secara jelas, singkat, dan bermakna positif, sedangkan pada nonverbal memperhatikan isyarat mimik muka, kontak mata, gerakan tangan, dan penggunakan busana yang sesuai.
\end{abstract}

Kata kunci: profil, negosiasi, bisnis, memasarkan, produk, jasa.

\section{Pendahuluan}

Pelaku usaha telah berperan aktif untuk memajukan roda perekonomian di Indonesia. Seperti di Jawa Barat, Wanita pengusaha memiliki peran penting dalam memajukan perekonomian daerah. Menurut Presiden Soesilo Bambang Yudhoyono wanita pengusaha "dapat mengembangkan diri menjadi entrepreneur sejati, opportunity seeker tapi juga creator seeker" (www.presidenri.go.id/index.php/fokus/2007/11/ 14/2427.html).

Wanita pengusaha dalam pengembangan bisnisnya perlu dukungan berbagai pihak, seperti kebijakan pemerintah, modal, pelatihan, dan sebagainya. Khusus untuk pengusaha kecil diperlukan "upaya pemberdayaan agar bisa terus berkembang" (Suara Karya Online, 8 Agutus 2008).

Aktivitas bisnis di bidang produk dan jasa dilakukan para wanita pengusaha tersebut. Kontribusinya terlihat pada peluang kesempatan kerja bagi masyarakat. Begitu juga di Jawa Barat, kegiatan bisnis para wanita pengusaha berkembang pesat. Mereka menjalankan usaha antara lain dengan melahirkan ide kreatif, seperti produk busana, kerajinan dan makanan (kue kering, kue basah, keripik, catering, dsb.), bidang transportasi, mebeuler, dan konveksi. Di bidang perdagangan, seperti menjual permata, baju, 
mukena, atau melakukan usaha yang mengandalkan jasa, misalnya rias pengantin, salon, hotel, travel, dan lain sebagainya.

Wanita pengusaha dalam menjalankan bisnisnya tidak selalu dalam kondisi yang mendukung, ada kalanya mengalami tantangan. Hal ini sesuai dengan pendapat Ketua Dewan Kerajinan Nasional Daerah Jawa Barat, Ny Netty Prasetyani Heryawan, "tantangan yang terjadi antara lain pada teknologi dan pemasaran" (Pikiran Rakyat, 22 November 2010).

Dalam masalah pemasaran, para pengusaha dituntut mencari peluang yang ditransformasikan menjadi penjualan. Untuk itu mereka perlu memiliki keterampilan dan seni penjualan yang menguntungkan. Hal lainnya adalah pada aspek permodalan, pengetahuan pengelolaan produk/jasa dan keterampilan negosiasi untuk mengembangkan bisnis.

Dalam mengelola usaha terjadi interaksi antara pengusaha dan pengguna produk atau jasanya. Banyak hal yang mereka lakukan di antaranya yaitu upaya untuk mencapai suatu kesepakatan kerjasama dengan pihak eksternal perusahaan.

Menyelenggarakan upaya tersebut bukan hal mudah. Pada saat perundingan berlangsung seorang negosiator melakukan berbagai aspek dalam negosiasi untuk memperlancar jalannya kerjasama yang akan berlangsung.

Interaksi itu mungkin dapat mengarah pada pertentangan, namun di antara kedua pihak itu terjadi saling memerlukan. Untuk mengatasinya perlu upaya mencapai titik temu dengan membicarakan secara terbuka perbedaan pandangan tersebut antara lain dengan memiliki kecakapan negosiasi.

Dengan menerapkan negosiasi, wanita pengusaha dapat mengelola dan mengembangkan bisnis untuk memasarkan produk dan jasa, maupun untuk maksud melakukan kerjasama dalam mengembangkan bisnisnya. Karena melalui negosiasi tersebut pelaku usaha diharapkan dapat membuat kesepakatan bisnis, terutama dalam penjualan.

Keterampilan negosiasi penjualan ini paralel dengan misi pemerintah dalam mengurus utamakan gender. Apabila wanita pengusaha semakin mahir dalam mengelola usahanya secara alamiah akan menjadi pemain-pemain utama dalam bidangnya dan cakap bernegosiasi dengan partner bisnisnya.

Salah satu pelaku usaha yang giat melakukan kegiatan bisnis adalah para wanita pengusaha yang tergabung dalam I katan Wanita Pengusaha (IWAPI) di kota Bandung. Menurut pendapat ketua IWAPI DPD Jawa Barat, "wanita pengusaha pada umumnya memiliki pengetahuan dan keterampilan negosiasi yang minim. Untuk menjalankan bisnisnya perlu negosiasi guna memasarkan produk dan jasa mereka" (wawancara dengan pengurus IWAPI Jawa Barat, Masrura Ramidjal, di Bandung, 18 J uni 2013).

Mencermati pendapat tersebut perlu dilakukan penelitian mengenai kemampuan negosiasi penjualan bagi wanita pengusaha di Jawa Barat. Dengan penelitian ini akan diketahui kemampuan wanita pengusaha memahami proses negosiasi dan melaksanakan negosiasi penjualan guna memasarkan produk atau jasanya. Berdasarkan latar belakang tersebut memberi gambaran perlunya dilakukan penelitian kemampuan negosiasi penjualan bagi wanita pengusaha yang tergabung dalam organisasi IWAPI Jawa Barat. Berdasarkan latar belakang masalah yang penulis uraikan, maka dapat dirumuskan suatu permasalahan sebagai berikut: bagaimana Profil Negosiator Bisnis Wanita Pengusaha pada Ikatan Wanita pengusaha (IWAPI) J awa Barat dalam Memasarkan Produk dan Jasa?

Adapun pertanyaan penelitian yang dapat dikemukakan yaitu bagaimana kemampuan negosiasi bisnis wanita pengusaha untuk membangun kerjasama, bagaimana kemampuan menggunakan pesan verbal dan nonverbal dan faktor apa yang menjadi penghambat wanita pengusaha dalam menjalankan negosiasi bisnis dalam memasarkan produk dan jasa?

Pendekatan penelitian ini menggunakan pendekatan kualitatif dengan studi kasus tunggal. Adapun pengumpulan data dilakukan dengan observasi untuk mengamati data lapangan, wawancara mendalam, untuk menggali data dan opini informan, serta kepustakaan.

\section{Negosiasi Bisnis}

Komunikasi sangat berperan dalam proses negosiasi bisnis yang dilakukan oleh pihak-pihak yang terlibat. Wanita pengusaha sebagai pelaku bisnis dalam menjalankan bisnisnya terus saling berhubungan, saling berinteraksi dan saling membutuhkan untuk dapat bekerja sama dengan orang lain. Alat untuk melaksanakan hubungan tersebut adalah komunikasi. Pada hakikatnya komunikasi adalah "proses pernyataan antar manusia yang dinyatakan itu adalah pikiran atau perasaan seseorang kepada orang lain dengan menggunakan bahasa sebagai penyalurnya" (Effendy, 1993: 27).

Dalam proses komunikasi paling sedikit terdapat tiga komponen dasar yang menjadi syarat mutlak agar proses tersebut berjalan, yaitu pengirim, penerima, dan pesan yang disampaikan oleh si pengirim kepada penerima (Prisgunanto, 2006:43).

Peristiwa komunikasi melibatkan sumber sebagai pembuat atau pengirim informasi. Dalam 
komunikasi antarmanusia, sumber bisa terdiri dari satu orang, tetapi bisa juga dalam bentuk kelompok seperti organisasi atau lembaga. Penerima adalah pihak yan menjadi sasaran pesan yang dikirim oleh sumber. Penerima bisa terdiri dari satu orang atau lebih, bisa dalam bentuk kelompok atau organisasi. Pesan yang dimaksud dalam proses komunikasi adalah sesuatu yang disampaikan dengan cara tatap muka atau melalui media komunikasi.

Proses komunikasi dalam negosiasi bisnis yang dilakukan oleh wanita pengusaha, termasuk ke dalam konteks komunikasi antarpribadi dan komunikasi kelompok kecil. Komunikasi antarpribadi menurut Joseph A. Devito, yaitu

\begin{abstract}
"Proses pengiriman dan penerimaan pesan-pesan antara dua orang, atau di antara sekelompok kecil orang-orang, dengan beberapa efek dan beberapa umpan balik seketika (dalam Effendy, 2000: 59). Sedangkan negosiasi adalah "proses tawarmenawar dengan jalan berunding untuk memberi dan menerima guna mencapai kesepakatan bersama yang saling menguntungkan" (Dawson, 2004).
\end{abstract}

Definisi negosiasi adalah suatu area yang penuh dengan pengetahuan dan usaha yang keras yang memfokuskan untuk mengumpulkan bantuanbantuan dari orang-orang tertentu (Cohen, 2005: 4). Yang dimaksud negosiasi di sini adalah menggunakan informasi dan kekuatan untuk memengaruhi tingkah laku ke dalam suatu "jaringan yang penuh tekanan" (Cohen, 2005: 4).

Negosiasi bisnis adalah suatu metode untuk mencapai perjanjian dengan unsur-unsur koperatif maupun kompetitif. Unsur koperatif berasal dari keinginan kedua belah pihak untuk mencapai kesepakatan yang dapat diterima bersama. Unsur kompetitif berasal dari keinginan kedua belah pihak untuk mencapai hasil terbaik bagi mereka sendiri (Schoomaker, 1993: 7).

Wanita pengusaha dan mitra bisnisnya juga diharapkan dapat menerapkan proses tawar menawar dengan berunding agar mencapai kesepakatan untuk kerjasama. Hal itu dapat diperoleh antara lain dengan komunikasi dan membangun hubungan yang baik, sehingga akan terjalin hubungan kerja sama yang baik. Salah satu bentuk negosiasi bisnis untuk membangun kerjasama adalah negosiasi kooperatif, yaitu

"Seluruh gagasan bertujuan mencapai solusi di mana semua orang mendapatkan manfaat. Pendekatan ini cenderung memberikan hasil terbaik, utamanya karena terjadi komunikasi yang lebih baik di antara semua pihak yang terlibat" (Prasetyono, 2007: 50).

Untuk memeroleh kerjasama yang baik di antara masing-masing pihak, negosiator perlu memulai dengan suasana yang ramah, dan menetapkan suatu ancangan yang bersifat bisnis, pertemuan pemikiran ke arah inti negosiasi, penetapan kerjasama sejak dini di antara kedua belah pihak, pemahaman bersama tentang urutan kegiatan yang dapat diantisipasi bersama, keterlanjutan dan pengembangan langkah mantap dan cepat yang sudah ditetapkan Scott, (1993: 23).

Guna memperoleh hasil negosiasi yang baik, pada proses pembukaan negosiator perlu menetapkan isi, prosedur, dan interaksi pribadi. Isi adalah rangkaian topik yang harus ditetapkan. Adapun maksud prosedur adalah perencanaan, formulasi agenda, pengendalian atas pertemuan, pengendalian atas pertemuan, persiapan tempat dan bahan negosiasi, berbagai persiapan awal di antara kedua belah pihak dan langkah lajunya. Sedangkan interaksi pribadi adalah cara orangorang tersebut terlibat dalam negosiasi satu sama lain. Dalam membahsa isi negosiasi mencakup tujuan, perencanaan, langkah, dan kepribadian (Scott, 1993: 24-25).

Agar tujuan negosiasi bisnis tercapai dengan baik, negosiator selain memersiapkan pembukaan negosiasi, perlu memperhatikan lima tahap dalam negosiasi, yaitu pertama, eksplorasi merupakan tahap negosiasi di mana masing-masing pihak memahami tuntutan pihak lain serta mulai timbul pengertian tentang permasalahan yang perlu diselesaikan. Kedua, Penawaran, salah satu atau kedua belah pihak memberikan penawaran lebih dahulu atau menyampaikan permasalahan yang dihadapinya dalam perjanjian itu. Ketiga, tawarmenawar, yaitu masing-masing pihak berusaha untuk melakukan negosiasi mengarah pada keuntungan terbaik bagi mereka. Keempat, penyelesaian, merupakan proses setelah tawarmenawar di mana masing-masing pihak mengakui bahwa persetujuan itu sudah di ambang pintu. Kelima, pengesahan, biasanya dalam bentuk tertulis dan seringkali dalam rincian hukum (Scott, 1993: 36-37).

Dalam prakteknya, terkadang tahap negosiasi tidak selalu mengikuti urutan tersebut. Namun, untuk mendapatkan pengendalian yang efektif atas proses negosiasi, negosiator harus menyadari adanya lima tahap tersebut. Tahaptahap negosiasi tersebut diharapkan dijalankan di dalam proses negosiasi yang berlangsung antara wanita pengusaha dengan mitra bisnisnya.

Dalam penawaran negosiasi melibatkan suatu permasalahan yang dimiliki kedua belah pihak, yang nantinya akan menuju pada proses tawar menawar. Pada proses tersebut kedua belah pihak harus memerhatikan dengan seksama apa yang harus dilakukan agar dapat menghindari adanya konsensi yang merugikan.

Dalam praktek negosiasi bisnis, proses komunikasi dimulai sejak kontak pertama sebelum proses negosiasi dilangsungkan. Dapat dikatakan bahwa negosiasi merupakan hasil dari proses komunikasi yang semakin intens. Perancangan melakukan negosiasi antara dua pihak merupakan indikasi sudah sampai atau diterimanya gagasan 
dari pihak pertama ke pihak kedua dan sebaliknya. Negosiasi pada dasarnya adalah proses komunikasi, di mana di dalamnya ada penyampaian gagasan, penyamaan persepsi atas gagasan, persuasi, dan kesepakatan. Masingmasing pihak yang bernegosiasi merupakan komunikator yang secara aktif mengomunikasikan gagasan tentang alternatif yang mungkin disepakati bersama dengan sejumlah argumentasi yang mendukung (Sujana, 2004: 13).

Selain berperan menjadi negosiator yang baik, negosiator perlu mengetahui langkah-langkah strategis (gambit) negosiasi. Setiap langkah yang ditempuh tentunya melibatkan resiko. Namun, dengan keterampilan negosiator dalam memilih gambit yang tepat dan menggunakannya dalam waktu yang tepat akan meminimalkan resiko tersebut.

Roger Dawson dalam bukunya yang berjudul Secrets of Power Negotiating membagi gambit negosiasi menjadi tiga gambit. Gambit-gambit negosiasi (Dawson, 2004: 1) tersebut terdiri dari gambit awal yang akan memulai permainan (negosiasi) sesuai dengan keinginan negosiator. Gambit-gambit tengah yang mempertahankan negosiasi tetap berkembang sesuai keinginan negosiator, dan gambit penutup yang siap menutup penjualan.

Agar situasi negosiasi dapat berjalan dengan baik, maka negosiator dituntut untuk dapat mengendalikan situasi negosiasi sehingga dalam kegiatan negosiasi tersebut dapat tercapai kesepakatan yang terbaik bagi masing-masing pihak yang terlibat.

Meskipun negosiasi bisnis merupakan kegiatan yang mungkin dilakukan oleh orangorang yang berbisnis, dalam melaksanakan negosiasi ini tidak mudah. Negosiator perlu menyiapkan diri sebaik-baiknya sebelum melakukan negosiasi. Karena negosiasi yang dilakukan mungkin berlangsung keras, masing-masing pihak ingin memertahankan tuntutannya. Bila negosiator mengalami keadaan ini, situasi komunikasi menjadi penuh ketegangan, dapat mengarah pada deadlock (kebuntuan) komunikasi.

Menjadi negosiator bisnis terampil perlu terus mengasah kemampuan pribadi, sehingga ia cakap dalam menjalankan negosiasinya. Salah satu hal yang akan mengasah kecakapan negosiator ini adalah kemampuan negosiator dalam melaksanakan pola negosiasi yang akan menghasilkan kesepakatan sebesar mungkin demi keuntungan kedua belah pihak. Pemahaman negosiator terhadap iklim negosiasi akan membantu kedua pihak bekerja sama, secara kreatif, ke arah persetujuan bersama. Mencapai suatu persetujuan merupakan sasaran negosiasi.

Seorang negosiator bisnis dituntut mampu bernegosiasi untuk menghasilkan kerjasama, namun apabila ia harus bersaing dengan pengusaha lain, dalam negosiasi hal itu disebut negosiasi kompetitif. Bila negosiator berada dalam kondisi ini, negosiator dituntut untuk tetap fokus pada tema yang dinegosiasikan, bersikap tenang, dan tegas dalam mengambil keputusan. Hal ini dimulai dengan memersiapkan diri negosiator, yaitu dengan melakukan tujuan yang spesifik, bisa dicapai, dan diukur. Artinya, tujuan yang negosiator tetapkan itu harus realistis. Penting juga untuk mengetahui secara jelas harapan negosiator dari pihak lawan (Prasetyono, 2007: 49).

Selanjutnya, bila tujuan yang ingin dicapai realistis, negosiator perlu menuliskan beberapa tujuan yang hendak dicapai tersebut, kemudian urutkan berdasarkan prioritasnya. Setelah itu kumpulkan sebanyak mungkin informasi tentang topik yang akan dibicarakan. Dengan demikian kesuksesan negosiasi tergantung pada perencanaan dan persiapan yang matang. Saat yang tepat merupakan hal yang penting (Prasetyono, 2007: 52-53).

Kemampuan menggunakan pesan verbal dan nonverbal oleh seorang negosiator juga merupakan salah satu kunci sukses negosiasi. Dengan kemampuan mengolah pesan tersebut diharapkan dapat terjalin kerjasama yang baik berasal dari ucapan atau pernyataan yang baik juga dari perilaku nonverbal atau bahasa tubuh.

Sebagian informasi disampaikan melalui tanda-tanda bahasa tubuh, yang sebagai besar berasal dari mata dan tangan. Memahami penggunaan bahasa tubuh dengan baik, "akan menambahkan dimensi baru menuju keterampilan persuasif. Hal ini diharapkan dapat menjalin hubungan dan mempengaruhi hasil-hasil yang diinginkan di dalam berbagai negosiasi" (Prasetyono, 2007: 88).

Pesan verbal adalah pesan dalam komunikasi yang berupa ucapan (lisan/kata-kata). Pesan nonverbal adalah penciptaan dan pertukaran pesan dengan tidak menggunakan kata-kata, seperti komunikasi yang menggunakan gerakan tubuh, sikap tubuh, vokal yang bukan kata-kata, kontak mata, ekspresi muka, kedekatan jarak dan sentuhan. Sebagai besar komunikasi yang digunakan untuk menyampaikan informasi disampaikan melalui bahasa tubuh (nonverbal). Sedangkan bagian-bagian untuk mengungkapkan nilai-nilai, perasaan, dan sikap lebih banyak disampaikan lewat bahasa verbal. Sebagai ilustrasi, menggunakan bahasa tubuh, terutama bahasa gerakan tangan bisa menguatkan pesan yang akan disampaikan (Prasetyono, 2007: 89).

Faktor penghambat dalam negosiasi menurut Bill Scott (1993: 82-84) pertama, negosiator tidak memperhatikan apa yang telah dikatakan pihak lain dan yang telah didengarnya. Hambatan tersebut berupa kebisingan, kurangnya 
konsentrasi, kepekaan, penyimpangan sewaktu transmisi, misalnya melalui telepon. Kedua, apapun yang mungkin didengar oleh pendengar, apa yang dimengertinya dipengaruhi oleh pendidikan, dan pengetahuan teknis mengenai masalahnya. Ketiga, kesediaan untuk menerima dipengaruhi oleh faktor-faktor psikologis: sikapnya terhadap pihak lain, sikapnya terhadap organisasi pihak lain, perasaaannya mengenai hal yang didiskusikan, pengalaman sebelumnya dalam hubungan dengan perusahaan atau produknya. Keempat, tidak memerhatikan pernyataan pesan balasan pihak lain.

\section{Negosiasi Bisnis Membangun Kerjasama dalam Memasarkan Produk dan J asa}

Data penelitian diperoleh peneliti melalui wawancara dengan wanita pengusaha yang dianggap mengerti masalah yang diteliti, serta observasi ketika proses negosiasi berlangsung. Karena itu informan penelitian ini adalah wanita pengusaha yang aktif dalam wadah I katan Wanita Pengusaha Indonesia Jawa Barat yang dikaji bersama-sama supaya subyek mewakili profil wanita pengusaha IWAPI. Penentuan informan pertama-tama berdasarkan pada pendapat Pengurus IWAPI Jabar, bahwa informan penelitian ini adalah unsur pimpinan yaitu pengurus inti IWAPI J awa Barat (ketua, sekretaris, bendahara, divisi Pengembangan Usaha), dan pengurus DPC IWAPI Jabar dengan memilih satu orang wanita pengusaha yang memiliki kemampuan usaha yang menonjol di bidang masing-masing dan di daerahnya. DPC IWAPI yang terpilih yaitu dari DPC Kota Bandung, Garut, Karawang, Cirebon, dan Kota Bogor.

Berdasarkan data IWAPI Jawa Barat, Wanita pengusaha yang tergabung sekitar 1200 orang (IWAPI Jabar, 2009). Mayoritas anggota IWAPI adalah para pengusaha kecil (85\%), sebagian lagi merupakan pengusaha tingkat menengah (12\%) dan sebanyak 3\% merupakan pengusaha golongan besar (IWAPI Jabar, 2009).

Hasil penelitian tentang jenis usaha yang ditekuni wanita pengusaha adalah catering, makanan ringan (kue kering, kue basah, dodol dan keripik), pakaian (pakaian muslim, dan batik), transportasi (taxi), travel (perjalanan wisata, dan ibadah), konveksi, pedagang berlian, dan restoran. Kemampuan negosiasi bisnis wanita pengusaha untuk membangun kerjasama dengan pengusaha lain diuraikan berdasarkan tahap-tahap negosiasi mencakup tahap eksplorasi, penawaran, tawarmenawar, penyelesaian, dan pengesahan. Wanita pengusaha menjalin kerjasama dengan pihak lain bertujuan untuk memperluas hubungan kerjasama. Kedua belah pihak yaitu mengadakan pertemuan dan membicarakan hendak melakukan kerjasama.

Tahap eksplorasi dalam negosiasi bisnis, wanita pengusaha sebagai negosiator berusaha memahami tuntutan pihak lain. J ika masing-masing pihak dapat memahami tuntutan pihak lain, maka akan mempermudah untuk mencapai suatu kesepakatan bersama yang dapat menguntungkan kedua belah pihak yang bernegosiasi.

Dalam tahap ini pula, bentuk kerjasama antara kedua belah pihak mulai jelas. Dalam artian bahwa, negosiasi yang terjadi antara keduanya mengarah kepada tercapainya kesepakatan bersama yang dapat menguntungkan kedua belah pihak Wanita pengusaha paham bahwa dalam negosiasi ini pihak lain sebagai pasar potensial bagi usaha mereka. Begitu pun sebaliknya. Proses memahami ini, didapatkan ketika masing-masing pihak mengungkapkan posisi mereka dalam kegiatan negosiasi ini.

Cara lain dalam penelitian ini wanita pengusaha untuk dapat memahami tuntutan pihak lain yaitu dengan melakukan penyelidikan atau penelitian sebelumnya untuk mendapatkan segala informasi mengenai lawan negosiasinya. Informasi di dalam IImu Komunikasi tidak dapat terpisahkan, sebab komunikasi merupakan suatu proses pemindahan atau pertukaran informasi. Mencari banyak informasi sebelum kegiatan negosiasi berlangsung dilakukan agar negosiator dapat memeroleh banyak peluang untuk menang. Seperti yang diutarakan oleh Michael Molnar (2000 dalam Sujana 2004: 21) dalam bukunya Retail Negotiator Guidance, menyatakan, "Semakin banyak informasi yang kita miliki, semakin baik aternatif yang bisa kita buat."

Menurut Jackman (2005: 23) "penelitian merupakan faktor yang sangat penting jika anda ingin berhasil sebagai negosiator." Penelitian yang cermat dan lengkap akan membangun kepercayaan diri seorang negosiator dalam bernegosiasi, sekaligus menambah pengetahuan dan informasi bagi negosiator tersebut.

Pada tahap penawaran dari pihak wanita pengusaha (pertama) kepada pihak kedua, yaitu berupa harga/ tarif pelayanan, cakupan pelayanan serta prosedur pelayanan. Proses tawar-menawar yang terjadi dalam proses negosiasi antara keduanya berkaitan dengan hal-hal yang ditawarkan dalam proses penawaran yang berupa penyamaan persepsi dan keinginan antara masing-masing pihak yang bernegosiasi.

Tahap penawaran dan tawar-menawar merupakan inti dari proses negosiasi. Menurut Scott (1993: 36),

"dalam tahap penawaran, salah satu atau kedua belah pihak memberikan penawaran lebih dahulu atau menyampaikan permasalahan yang dihadapinya dalam perjanjian itu." 
Setelah tahap penawaran kemudian dilanjutkan dengan tahap tawar-menawar yang berlangsung dari satu pihak ke pihak lain. Menurut Scott (1993: 36)

"Dalam tahap tawar-menawar, masing-masing pihak berusaha untuk melakukan negosiasi mengarah pada keuntungan terbaik bagi mereka."

Berdasarkan temuan penelitian ini, penawaran yang diajukan oleh masing-masing pihak dituangkan dalam bentuk tertulis terutama mengenai hal cakupan pelayanan. Sesuai dengan yang diutarakan oleh Schoonmaker (1993: 103), "dalam negosiasi yang kompleks sebagian besar penawaran harus dibuat atau ditegaskan dalam bentuk tulisan". Penawaran yang tertulis sangatlah efektif, karena meskipun apa yang dipikirkan akan dikatakan, namun terdapat kemungkinan berbeda dengan apa yang didengar oleh pihak lawan.

Setelah proses penawaran serta tawarmenawar berlangsung, maka tahap berikutnya yaitu tahap penyelesaian. Scott (1993: 37) menyatakan, "tahap penyelesaian, merupakan proses setelah tawar-menawar di mana masingmasing pihak mengakui bahwa persetujuan itu sudah di ambang pintu." Tahap ini ditemui setelah situasi negosiasi yang terjadi dalam tahap tawarmenawar mengarah kepada pergerakan ke arah persetujuan yang berujung kepada tercapainya kesepakatan bersama. Berdasarkan hasil wawancara dalam negosiasi antara wanita pengusaha dengan pihak lain, penyelesaian dicapai oleh masing-masing pihak menuju ke arah negosiasi menang-menang (win-win).

Robert Dawson (2004: 351) mengatakan bahwa seorang negosiator yang handal atau seorang power negotiator harus memiliki atau mengembangkan karakteristik personal berikut ini: "keberanian untuk menggali lebih banyak informasi, kesabaran untuk bertahan lebih lama daripada negosiator lawan, keberanian untuk meminta lebih daripada yang anda harapkan, integritas untuk menekan tercapainya solusi menang-menang, dan kesediaan untuk menjadi pendengar yang baik.

Hasil penelitian tentang karakteristik personal negosiator ditemukan bahwa, pertama, keberanian untuk menggali lebih banyak informasi, dalam proses negosiasi sangat diperlukan, sebab informasi adalah kekuatan dalam bernegosiasi. Semakin banyak informasi yang didapat, semakin akurat informasi yang dimiliki, maka kekuatan tawar-menawar akan semakin kuat. Negosiator pihak pertama memiliki informasi yang dibutuhkan mengenai pihak kedua, sehingga ketika pelaksanaan negosiasi dapat memberikan ruang gerak yang luas dalam melakukan tawar-menawar.

Kedua, kesabaran untuk bertahan dilakukan oleh negosiator pihak pertama. Hal itu terlihat ketika kedua belah pihak melakukan proses tawarmenawar. Memiliki kesabaran untuk bertahan lebih lama dari negosiator lawan merupakan salah satu karakteristik yang penting untuk dimiliki oleh seorang negosiator, sebab kesabaran dapat memberikan keuntungan bagi seorang negosiator.

Kesediaan menjadi pendengar yang baik dimulai dari kesediaan menanggapi pihak lain dalam bernegosiasi. Negosiator yang handal pertama-tama akan memastikan bahwa ia mengetahui apa yang ditawarkan oleh pihak lawan. Sikap menanggapi pihak lain dapat dilakukan dengan keterampilan komunikasi yang efektif seperti mendengarkan. Ann Jackman (2005: 56) menyatakan, "mendengarkan dengan efektif akan membantu negosiator mengenali titik kunci dalam argumen lawan negosiasi". Dengan demikian negosiator dapat memahami dan menghargai keberatan pihak lawan terhadap proposal yang diajukan.

Menurut Dawson (2004: 20), terdapat langkah awal atau gambit awal dalam negosiasi yang berbunyi, Jangan pernah katakan 'Ya' terhadap tawaran pertama. Dalam melakukan negosiasi, wanita pengusaha sebagai negosiator tidak pernah mengatakan 'Ya' pada tawaran pertama yang diberikan oleh pihak lawan.

Berdasarkan wawancara dengan beberapa wanita pengusaha, mereka terlebih dahulu menganalisis dan mengkaji penawaran yang diberikan pihak lawan terutama pada setiap penawaran harga. Hal tersebut dilakukan sebab mereka pada umumnya memiliki perbandingan harga tertinggi (harga maksimal). Oleh karena itu, sebisa mungkin harga yang didapatkan tidak melewati harga maksimal. Selain itu, dengan menganalisis terlebih dahulu penawaran yang diberikan pihak lawan dan dengan tidak mengatakan "Ya" pada tawaran pertama, maka wanita pengusaha sebagai negosiator dapat memperhitungkan kemampuan bayar perusahaannya dengan harga yang ditawarkan, sehingga diharapkan dapat memberikan hasil kesepakatan yang dapat menguntungkan. Sebetulnya beberapa taktik negosiasi pada dasarnya sudah mereka lakukan dalam menjalankan bisnisnya, terutama misalnya, bila ada calon pembeli yang menawar produk atau jasa yang mereka tawarkan, mereka tidak langsung setuju dengan harga yang disampaikan pembeli.

Penelitian ini juga menemukan bahwa para wanita pengusaha memiliki nilai-nilai yang dijaga kuat, sebagai seorang muslimah, mereka selalu menjaga komitmen, menjaga amanah, bersikap jujur, tidak pernah melakukan penurunan nilai jasa. Mereka memiliki semangat yang kuat untuk terus konsisten berbisnis sampai berhasil memuaskan mitranya. Di samping itu ada nilai-nilai spiritual yang dijaga seperti berdo'a kepada Allah SWT 
MIMBAR, Vol. 29, No. 2 (Desember, 2013): 235-244

supaya bisnisnya lancar, barokah, mengeluarkan zakat usaha, dan shodaqoh dari keuntungannya yang cukup besar.

Dalam pandangan Islam, tindakan wanita pengusaha itu baik menurut akal atau rasio, rasa atau kalbu dan agama, maka tindakan itu disebut akhlak yang baik (akhlakul karimah). Hal ini sesuai dengan pendapat Iskandar (dalam Mimbar Volume
23, No. 1, 2007), "akhlak yang baik adalah dorongan dari keimanan yang ditampilkan dengan tindakan nyata dalam kehidupan." Aktivitas bisnis mereka berdasarkan nilai-nilai moral, norma, etika dan agama yang dijadikan tuntunan untuk membuat keputusan dan solusi masalah. Mereka melaksanakan prinsip dan standar etika bisnis, yaitu: kejujuran, memegang prinsip dan keyakinan,

Tabel 1

Profil Kemampuan Negosiasi Bisnis Wanita Pengusaha dalam Memasarkan Produk dan Jasa

\begin{tabular}{|c|c|c|c|}
\hline No & $\begin{array}{l}\text { Kemampuan } \\
\text { Negosiasi Bisnis }\end{array}$ & & Uraian \\
\hline 1 & $\begin{array}{l}\text { Kemampuan negosiasi bisnis } \\
\text { untuk membangun } \\
\text { kerjasama }\end{array}$ & $\begin{array}{l}\text { Tahap negosiasi : } \\
\text { a. Eksplorasi } \\
\text { b. Penawaran } \\
\text { c. Tawar-menawar } \\
\text { d. Penyelesaian } \\
\text { e. Pengesahan }\end{array}$ & $\begin{array}{l}\text { - Timbul pengertian } \\
\text { - Memahami tuntutan pihak lain } \\
\text { - Meneliti informasi dari pihak lain } \\
\text { - Harga } \\
\text { - Cakupan pelayanan } \\
\text { - Prosedur pelayanan } \\
\text { - Memeriksa informasi penawaran } \\
\text { - Penawaran dituangkan secara tertulis } \\
\text { - Penawaran disampaikan secara tegas } \\
\text { - Masing-masing pihak setuju/ sepakat } \\
\text { - Terdapat kesamaan hasil yang } \\
\text { diinginka kedua belah pihak } \\
\text { - Buat ringkasan } \\
\text { - Kesepakatan dalam MoU } \\
\text { ditandatangan kedua belah pihak, } \\
\text { atau disahkan ke notaris. }\end{array}$ \\
\hline 2 & $\begin{array}{l}\text { Kemampuan negosiasi bisnis } \\
\text { untuk bersaing dengan } \\
\text { pengusaha lain }\end{array}$ & $\begin{array}{l}\text { 1. Karakteristik } \\
\text { personal } \\
\text { negosiator } \\
\text { 2. Taktik negosiasi }\end{array}$ & $\begin{array}{l}\text { - Berani menggali lebih banyak informasi } \\
\text { - Sabar bertahan lebih lama dari } \\
\text { negosiator lawan } \\
\text { - Berani meminta lebih banyak } \\
\text { - Bersedia menjadi pendengar yang baik } \\
\text { - Menjaga amanah (kepercayaan) } \\
\text { - Jujur, Konsisten, Barokah, } \\
\text { - Selalu bersyukur } \\
\text { - Aplikasi taktik "J angan katakan ya } \\
\text { terhadap tawaran pertama” }\end{array}$ \\
\hline 3 & $\begin{array}{l}\text { Penggunaan pesan verbal } \\
\text { dan nonverbal }\end{array}$ & $\begin{array}{l}\text { 1. Pesan verbal: } \\
\text { 2. Pesan Nonverbal: }\end{array}$ & $\begin{array}{l}\text { - Pemakaian kata yang jelas } \\
\text { - Singkat, Bermakna positif } \\
\text { - Kontak mata dalam negosiasi tatap muka } \\
\text { - Pemakaian busana yang sesuai } \\
\quad \text { saat negosiasi }\end{array}$ \\
\hline 4 & $\begin{array}{l}\text { Faktor penghambat } \\
\text { negosiasi bisnis }\end{array}$ & Faktor penghambat: & $\begin{array}{l}\text { - Pengetahuan tentang negosiasi bisnis } \\
\text { terbatas } \\
\text { - Kurang memiliki karakteristik kepribadian } \\
\text { yang kuat } \\
\text { - Kurang memiliki sikap positif sebagai } \\
\text { negosiator } \\
\text { - Kurang memiliki keyakinan sebagai } \\
\text { negosiator }\end{array}$ \\
\hline
\end{tabular}

Sumber: Data Penelitian 
memelihara janji, komitmen dan dapat dipercaya, kesetiaan, kerjasama, dan bertanggungjawab."

\section{Pesan Verbal dan Nonverbal dalam Memasarkan Produk dan J asa}

Kemampuan menggunakan pesan verbal dan nonverbal negosiator merupakan salah satu kunci sukses negosiasi. Kemampuan mengolah pesan ini akan menghasilkan komunikasi yang baik, sehingga diharapkan dapat terjalin kerjasama yang baik. Komunikasi yang terjalin dengan baik tidak berasal dari ucapan atau pernyataan yang baik saja, tetapi juga dari perilaku nonverbal atau bahasa tubuh dari pihak-pihak yang terlibat.

Pesan verbal adalah pesan komunikasi berupa ucapan (lisan/kata-kata). Pilihan kata (diksi) dalam pesan komunikasi memiliki peran penting untuk mencapai keberhasilan komunikasi, begitu juga dalam negosiasi bisnis.

Pesan nonverbal adalah penciptaan dan pertukaran pesan menggunakan gerakan tubuh, sikap tubuh, vokal yang bukan kata-kata, kontak mata, ekspresi muka, kedekatan jarak dan sentuhan (Prasetyono, 2007:89).

Temuan penelitian mengenai penggunaan pesan verbal dalam memasarkan produk dan jasa adalah wanita pengusaha sebagai negosiator umumnya selalu menanggapi dengan cermat pesan yang disampaikan oleh negosiator lawan, berusaha menyusun pesan komunikasi yang bermakna positif. Pesan positif menurut Oswald (2009) mengandung energi tinggi, yang akan meningkatkan perasaan riang, pengharapan, dsb. Agar memperoleh pengaruh positif, individu dapat mengubah pola pikir dan bahasanya yang diterapkan pada percakapan internal dan eksternal melalui latihan mengganti kata berenergi rendah dengan kata berenergi tinggi. Mengubah pesan negatif ke pesan positif dalam kehidupan perlu mengikuti ketentuan bahwa suatu realitas mesti diungkapkan secara positif. Karena sesuai dengan karakteristik pikiran bawah sadar, bila seseorang menggunakan kata-kata negatif, ia akan menerima dan mewujudkan perasaan utama pikiran negatif itu. Dengan demikian kesuksesan dan kegagalan seseorang dimulai dari seberapa jauh ia dapat berbahasa secara positif yang akan berdampak pada kehidupan yang dijalaninya (dalam Ratnasari, Mimbar, Volume XXVI, No. 2, Desember 2010: 160-161, ejournal. ac.id).

Data yang diperoleh dari hasil wawancara terdapat hal-hal yang dilakukan negosiator dalam menanggapi pihak lawan yaitu mengamati gerakan bibir lawan ketika mereka sedang berbicara, mengamati mata lawan bicara ketika sedang berbicara, memusatkan perhatian pada pesan yang mereka sampaikan, membuat catatan untuk membantu konsentrasi, dan mengelompokan masukan yang diterima dari pihak lawan.

Penggunaan pesan nonverbal merupakan topik penting dalam negosiasi. Negosiator perlu mengamati secara tepat apa yang sedang lawan pikirkan dan rencanakan berdasarkan tanda-tanda dalam komunikasi nonverbalnya. Namun, hal ini

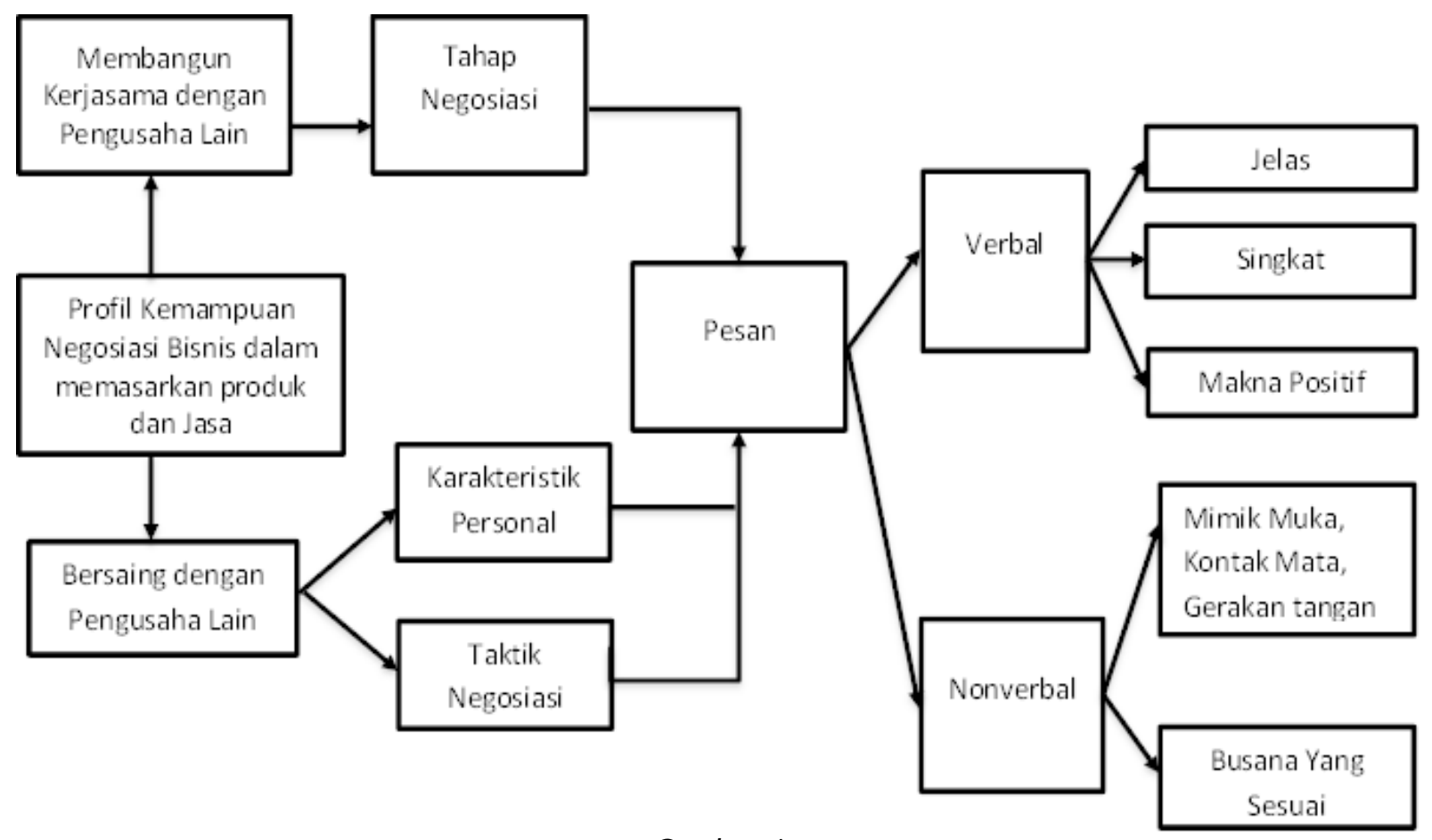

Gambar 1

Model Penelitian 
tidaklah mudah, sebab komunikasi nonverbal memerlukan kehati-hatian dalam memaknainya.

Pemahaman terhadap kontak mata bagi wanita pengusaha penting apabila berada dalam proses negosiasi yang bertemu-muka (face-toface). Dalam proses demikian maka negosiator selain harus terampil menggunakan berbagai taktik negosiasi atau gambit negosiasi, juga memiliki kemampuan menerapkan strategi komunikasi, terutama dalam memahami gerak mata lawan negosiasi (kerling matanya).

\section{Faktor Penghambat Negosiasi Bisnis Dalam Memasarkan Produk Dan J asa}

Temuan penelitian tentang faktor penghambat negosiasi bisnis adalah pengetahuan wanita pengusaha mengenai negosiasi bisnis secara teoritis masih terbatas, antara lain: karakteristik kepribadian, sikap dan keyakinan negosiator yang kurang dikembangkan, selain itu mereka juga kurang memiliki pengetahuan mengenai tahap-tahap negosiasi, taktik negosiasi, dan keterampilan dalam mengolah pesan komunikasi secara verbal dan nonverbal.

Sebetulnya terdapat upaya yang telah dilakukan para pengurus untuk menambah wawasan anggotanya dengan bekerja sama dengan berbagai pihak guna meningkatkan pengetahuan bisnis pada umumnya, dan pengetahuan tentang negosiasi pada khususnya. Hal tersebut dilakukan sejalan dengan upaya Pemerintah membantu UMKM dalam membina dan mengembangkan usaha, tepatnya untuk meningkatkan pengetahuan dan keterampilan mengelola bisnis wanita pengusaha.

Hambatan lain yang ditemukan adalah upaya apa yang harus dilakukan apabila dalam negosiasi kesepakatan tidak tercapai. Salah satu upaya yang dapat ditempuh dengan menunda permasalahan tersebut. Misalnya dalam proses negosiasi yang berkepanjangan, bila di antara kedua belah pihak menghadapi rintangan yang terjadi dalam negosiasi, yaitu seperti situasi impasse. Hal tersebut menurut Dawson (2004) tergolong kepada gambit negosiasi tengah.

Berdasarkan uraian terdahulu, dapat diringkaskan temuan penelitian yang merupakan keunikan yang didapat dari para wanita pengusaha disajikan dalam Tabel 1.

Hasil penelitian memperlihatkan profil kemampuan negosiasi bisnis wanita pengusaha dalam memasarkan produk dan jasa memiliki kekhususan tersendiri. Hal itu digambarkan dalam Gambar 1.

\section{Simpulan dan Saran}

Pertama, kemampuan negosiasi bisnis wanita pengusaha untuk membangun kerjasama dengan pengusaha lain diperoleh dengan bernegosiasi berdasarkan tahap-tahapnya. Dalam tahap eksplorasi, wanita pengusaha dapat memahami tuntutan pihak lain. Proses penawaran dan tawar-menawar dilalui dengan waktu yang cukup panjang, namun proses tersebut berjalan lancar dan cukup baik. Negosiator memiliki karakteristik personal yang baik dalam melakukan tawar-menawar terhadap penawaran dari pihak lain. Proses penyelesaian dilalui oleh kedua belah pihak berjalan dengan baik. Masing-masing pihak telah mendapatkan apa yang telah diinginkan dan menguntungkan kedua belah pihak. Kedua, wanita pengusaha memiliki kemampuan negosiasi bisnis dalam bekerjasama dengan pengusaha lain. Hal itu ditemukan bahwa mereka memiliki karakteristik personal yang berani menggali lebih banyak informasi, sabar untuk bertahan lebih lama daripada negosiator lawan, dan bersedia menjadi pendengar yang baik.

Ketiga, wanita pengusaha mampu menggunakan pesan verbal dan nonverbal dalam memasarkan produk dan jasa. Hal ini difokuskan pada keterampilan memahami gerak mata lawan negosisasi (kerling matanya). Karena dengan mengamati kerling mata lawan negosiasi memberi informasi kepada negosiator mengenai apa yang dipikirkan, dirasakan, atau keputusan apa yang akan diambil negosiator lawan terkait topik yang dibahas saat negosiasi. Keempat, faktor penghambat wanita pengusaha menjalankan negosiasi bisnis dalam memasarkan produk dan jasa adalah pengetahuan mengenai negosiasi bisnis secara teoritis masih terbatas, sikap dan keyakinan negosiator yang harus terus dikembangkan

Saran dalam penelitian ini pertama, wanita pengusaha perlu mengasah kemampuan dalam menjalankan negosiasi untuk kerjasama melalui upaya menerapkan tahap negosiasi secara baik, periksa langkah-langkahnya, dan selalu mengecek bahwa kesepakatan tersebut untuk memperoleh keuntungan bersama. Kedua, wanita pengusaha perlu mengupayakan peningkatan kemampuan negosiasi bisnis dalam bekerjasama dengan pengusaha lain melalui peningkatan kepribadian yang menunjang negosiator handal dengan berani menggali informasi, memiliki kesabaran, dan bersedia menjadi pendengar yang baik. Hal tersebut dapat terwujud dengan terus membina diri melalui serangkaian latihan negosiasi lebih banyak guna memperoleh peluang yang menguntungkan dari negosiasi bisnis.

Ketiga, wanita pengusaha mampu menggunakan pesan verbal dan nonverbal dalam memasarkan produk dan jasa. Penggunaan pesan nonverbal difokuskan pada latihan mengamati kerling mata lawan negosiasi. Keempat, upaya mengatasi faktor penghambat wanita pengusaha 
YUSUF HAMDAN, DKK. Profil Negosiator Bisnis Wanita Pengusaha

menjalankan negosiasi bisnis dalam memasarkan produk dan jasa antara lain dengan sering mengikuti pelatihan tentang negosiasi agar pengetahuan mereka mengenai negosiasi meningkat. Juga sering mengamati dan membina diri sebagai negosiator handal.

\section{Daftar Pustaka}

Cohen, Steven. 2006. Negotiate This! (Bernegosiasi dengan Hati). Terj.Agus Maulana. Batam: Karisma Publishing Group.

Dawson, Roger. 2004. Secret of Power Negotiating; Rahasia Sukses Seorang Negosiator Ulung. C. Louis Novianto (penerjemah). Jakarta: PT. Gramedia Pustaka Utama.

Effendy, Onong Uchjana. 2000. Ilmu, Teori dan Filsafat Komunikasi. Bandung: PT. Citra Aditya Bakti.

Iskandar. Peranan Etika Bisnis dalam Pembangunan Akhlak Mulia. Mimbar Volume 23, No. 1, 2007, ejournal. ac.id.

IWAPI Jawa Barat 2009, Company Profile.
Jackman 2005. Teknik Sukses Bernegosiasi. Jakarta: Gramedia.

Prasetyono, Dwi Sunar. 2007. Seni Kreatif Lobi dan Negosiasi. Yogyakarta: Think.

Pikiran Rakyat. Usaha Kerajinan Perempuan di Jabar Masih Terkendala. 22 November 2010.

Prisgunanto, Ilham. 2006. Komunikasi Pemasaran; Strategi dan Taktik. Bogor: Ghalia Indonesia.

Ratnasari, Anne. Pesan Positif dalam Komunikasi. Mimbar, Volume XXVI, No. 2, Desember 2010, ejournal. ac.id.

Scott, Bill. 1993. Strategi dan Teknik Negosiasi. Jakarta: PT. Pustaka Binaman Presstindo.

Schoonmaker, Alan N. 1993. Langkah-Langkah Memenangkan Negosiasi, Pustaka Binaman Pressindo, J akarta.

Sujana, Asep. 2004. Retail Negotiator Guidance: Menyingkap Rahasia Sukses Global Retailer. Jakarta: PT. Gramedia Pustaka Utama.

www.presidenri.go.id/index.php/fokus/2007/11/14/ 2427.html. 